\title{
Collagen diseases as a cause of constrictive pericarditis
}

\author{
D. K. C. COOPER ${ }^{1}$, W. P. CLELAND, AND H. H. BENTALL
}

From the Department of Surgery, Hammersmith Hospital and Royal Postgraduate Medical School, Ducane Road, London W12 OHS, UK

Cooper, D. K. C., Cleland, W. P., and Bentall, H. H. (1978). Thorax, 33, 368-371. Collagen diseases as a cause of constrictive pericarditis. Seven patients with constrictive pericarditis associated with collagen disease underwent pericardiectomy with good results in all but one. The collagen disease was confirmed as rheumatoid arthritis in five patients, but in two its nature remained obscure. In one case the illness was marked by a persistent eosinophilia and eosinophilic infiltration of the pericardium. The association of constrictive pericarditis with rheumatoid arthritis and other collagenoses is briefly discussed.

The first reports of constrictive pericarditis occurring in patients with rheumatoid arthritis were published by McMurray and his colleagues (1951) and Gimlette (1959). Since then, the association of rheumatoid arthritis with constrictive pericarditis has been reported in a sufficiently large number of patients to make the aetiological connection extremely likely. By 1966, 15 cases had been reported in the English language (Kennedy et al., 1966). No one institution or author has a large experience of such cases; the five cases reported by Gimlette form the largest series to date.

\section{Present series}

Since 1968, 29 patients at the Hammersmith Hospital have undergone pericardiectomy for constrictive pericarditis. In 11 cases the aetiology was considered to be tuberculous, although in not every case was there bacteriological or histological proof. Eight other patients displayed features of a collagen disease, which was positively identified as rheumatoid arthritis in six, the exact diagnosis being less clear in the remaining two. One of the six patients with rheumatoid arthritis was also found to have active tuberculosis, making the cause of her pericardial constriction uncertain. The ages of the patients at the time of onset of the collagen disease and at the time of operation are shown in the Table. Of the remaining ten patients, the constriction was associated with uraemia in one case and with carcinomatous infiltration of

'Present address: Thoracic Unit, Hospital for Sick Children, Great Ormond Street, London WC1. the pericardium in another; in the remainder the aetiology remained unproved but was presume to be viral.

\section{RHEUMATOID ARTHRITIS}

Each of the six patients diagnosed as suffering from rheumatoid arthritis had the typical clinicat features of the condition according to the criteriæ of the American Rheumatism Association (1959) the diagnosis was confirmed by the relevant laboratory tests, notably the latex fixation test for rheumatoid factor and the Rose Waaler, whic gave positive results in all cases except one (Table) In no case was there a significant history of viral pericarditis, and in no case except the one alreadmentioned was there any evidence of infection with the tubercle bacillus. This one patient, in whom tubercle bacilli were cultured from sputum gastric washings, and urine, and in whom serunty antibodies to the tubercle bacillus were present to. a titre of 1 in 125 , will be excluded from furthero discussion as the aetiology of the constriction was uncertain. The excised pericardium showed no features of tuberculosis, but by this time the patient was receiving triple chemotherapy.

The remaining five cases had typical clinical and investigative features of constrictive pericarditis and could not be differentiated by any haemo* dynamic feature from cases not associated witł rheumatoid arthritis (Dayem et al., 1967). Clinicol features of rheumatoid arthritis had been preserif for from two to 19 years before operation for cons striction of the heart was necessary (Table).

Two of the patients exhibited other complicas tions of rheumatoid arthritis, notably peripher영 
Table Clinical and serological features of patients developing constrictive pericarditis in association with collagen disease

\begin{tabular}{|c|c|c|c|c|c|c|c|c|c|c|}
\hline \multirow{2}{*}{\multicolumn{2}{|c|}{$\begin{array}{l}\text { Case no. } \\
\text { and sex }\end{array}$}} & \multirow{3}{*}{$\begin{array}{l}\begin{array}{l}\text { Age at } \\
\text { onset of } \\
\text { collagen } \\
\text { disease }\end{array} \\
42\end{array}$} & \multirow{3}{*}{$\begin{array}{l}\text { Age at } \\
\text { peri- } \\
\text { cardiectomy }\end{array}$} & \multicolumn{4}{|c|}{ Serology } & \multirow{3}{*}{$\begin{array}{l}\text { Diagnosis } \\
\text { RA }\end{array}$} & \multirow{4}{*}{$\begin{array}{l}\text { Extent of collagen disease } \\
\text { at pericardiectomy }\end{array}$} & \multirow{3}{*}{$\begin{array}{l}\begin{array}{l}\text { Activity of collagen } \\
\text { disease and } \\
\text { medication at } \\
\text { pericardiectomy }\end{array} \\
\begin{array}{l}\text { Moderately active. } \\
\text { Prednisone } 6 \mathrm{mg} \\
\text { daily. Ibuprofen }\end{array}\end{array}$} \\
\hline & & & & $L F T$ & $R \boldsymbol{W}$ & $A N F$ & $L C$ & & & \\
\hline 1 & $\mathbf{M}$ & & & + & + & & & & & \\
\hline 2 & $\mathbf{F}$ & 46 & 56 & + & + & - & - & $\mathbf{R A}$ & & $\begin{array}{l}\text { Almost 'burnt } \\
\text { out'. } \\
\text { Indomethacin } \\
\text { suppositories. } \\
\text { DF } 118\end{array}$ \\
\hline 3 & $\mathbf{M}$ & 59 & 63 & + & + & & - & $\mathbf{R A}$ & $\begin{array}{l}\text { Multiple arthropathy. } \\
\text { Soft tissue swelling. } \\
\text { Skin ulceration }\end{array}$ & $\begin{array}{l}\text { Active. } \\
\text { Prednisone } 14 \mathrm{mg} \\
\text { daily }\end{array}$ \\
\hline 4 & $\mathbf{F}$ & 39 & 47 & + & + & & & RA & $\begin{array}{l}\text { Multiple arthropathy. } \\
\text { Skin ulceration. } \\
\text { Joint effusions }\end{array}$ & $\begin{array}{l}\text { Active. } \\
\text { Prednisone } 7 \cdot 5 \\
\text { and } 5 \mathrm{mg} \text { alternate } \\
\text { days. Distalgesic }\end{array}$ \\
\hline 5 & $\mathbf{F}$ & 52 & 71 & $\stackrel{+}{\text { (weak) }}$ & - & & & RA & Multiple arthropathy. & $\begin{array}{l}\text { Inactive. } \\
\text { No treatment }\end{array}$ \\
\hline 6 & $\mathbf{F}$ & 48 & 55 & + & + & $\stackrel{+}{\text { (weak) }}$ & & $\begin{array}{l}\text { ?RA } \\
\text { ?TB }\end{array}$ & $\begin{array}{l}\text { Multiple arthropathy. } \\
\text { Soft tissue swelling }\end{array}$ & $\begin{array}{l}\text { Moderately active. } \\
\text { Prednisone } 5 \text { and } \\
2 \cdot 5 \text { mg alternate } \\
\text { days. Indomethacin } \\
25 \mathrm{mg} \text { tds }+ \\
\text { suppositories }\end{array}$ \\
\hline 7 & $\mathbf{F}$ & 17 & 21 & + & + & + & - & ?SLE & $\begin{array}{l}\text { Asthma, rhinitis. } \\
\text { (Eosinophilia) }\end{array}$ & $\begin{array}{l}\text { Moderately active. } \\
\text { Prednisolone } \\
8 \mathrm{mg} \text { daily }\end{array}$ \\
\hline 8 & $\mathbf{F}$ & 18 & 23 & - & & - & - & ??SLE & Pleural effusions & $\begin{array}{l}\text { Moderately active. } \\
\text { Prednisone } 20 \mathrm{mg} \\
\text { daily }\end{array}$ \\
\hline
\end{tabular}

RA = rheumatoid arthritis; TB = tuberculosis; $\mathbf{S L E}=$ systemic lupus erythematosus; $\mathbf{L F T}=$ latex fixation test; $\mathbf{R W}=\mathbf{R o s e} \mathrm{Waaler} ; \mathrm{ANF}=\mathbf{a n t i}$. nuclear factor; $\mathbf{L C}=$ lupus cells.

neuropathies, Baker's cysts, and peripheral vasculitis.

The histological appearances of the excised pericardia were non-specific cellular infiltration and fibrosis; calcification was not present.

All patients were greatly improved after pericardiectomy, and the improvement has been maintained to date in four cases. The oldest patient (case 5) developed congestive cardiac failure six months after operation and needed considerable medical treatment until the sudden onset of complete heart block caused her death two years later. Necropsy showed evidence of old pulmonary infarctions and myocardial hypertrophy but no residual pericardial constriction.

\section{OTHER COLLAGENOSES}

Two additional patients in the Hammersmith Hospital series of 29 were considered to be cases of constrictive pericarditis associated with collagen disease, although in neither case was the diagnosis absolutely clear (Table). One appears to be the first reported in the UK of pericarditis associated with eosinophilia and eosinophilic infiltration of the pericardium.

The patient was a 17-year-old girl who, in 1964, developed status asthmaticus which was treated with prednisone and antibiotics. Later the same year, she was found to have arthralgia, ecchymoses, a rash, and pericardial friction. Results of serological tests for rheumatoid arthritis were positive. She subsequently developed a butterfly rash on the face. Antinuclear factor (positive fluorescent antibody for lupus erythematosus) was present in the serum, suggesting a diagnosis of lupus erythematosus, although lupus cells were never identified. One unusual feature was that the eosinophil count was $12760 / \mathrm{mm}^{3}$ $\left(12.7 \times 10^{9} / 1\right)$ out of a total white cell count of $22000 / \mathrm{mm}^{3}\left(22.0 \times 10^{9} / 1\right)(58 \%$ of the total white cell count). She was again treated with prednisone.

Three years later the patient developed signs of right heart failure with some clinical evidence of constrictive pericarditis, which was supported by cardiac catheterisation studies. The eosinophil count was by now $18000 / \mathrm{mm}^{3}\left(18.0 \times 10^{9} / 1\right)$. At operation, the pericardium was thickened (3-4 mm) and constricted; the myocardium appeared normal. Pericardiectomy was performed. Histologically, the excised pericardium showed fibrous thickening with a mild inflammatory infiltrate mainly of polymorphs and eosinophils. There has been 
complete recovery of cardiovascular function, but the eosinophilia has persisted despite steroid therapy.

One other patient was also suspected of having systemic lupus erythematosus, although the diagnosis was never proved. At the age of 18 years she was admitted to another hospital with a febrile illness, bilateral pleural effusions, and abdominal pain. The abdominal symptoms and signs were sufficient to persuade the surgeons concerned to perform a laparotomy, but no abnormality was discovered. A clinical diagnosis of systemic lupus erythematosus was made, although testing for antinuclear factor and screening for lupus cells in the blood failed to substantiate this. After operation the patient developed a superior vena caval thrombosis. A high dose of steroid controlled the accumulation of pleural fluid; reduction of the dose caused the effusions to recur.

In 1970, some five years after the onset of her illness, she was referred to the Hammersmith Hospital. The patient displayed signs of constrictive pericarditis confirmed by cardiac catheterisation studies, and hypersteroidism. At operation, the heart was small and encased in an oedematous, thickened $(5 \mathrm{~mm})$ pericardium; the epicardium was also thickened $(3 \mathrm{~mm})$. Both pericardium and epicardium were stripped off and the heart increased spectacularly in size. After operation, the signs of pericardial constriction disappeared, and it was possible to reduce and eventually discontinue her steroid intake.

Clinical opinion at that time was that the patient's febrile illness had been due to a virus rather than systemic lupus erythematosus, but the control of the pleural effusions over several years with steroids supports the latter diagnosis.

\section{Discussion}

The Hammersmith Hospital series almost certainly gives a false impression of the frequency of the collagen diseases as a cause of constrictive pericarditis. The incidence is high because of the proximity of the rheumatology department at the Hammersmith Hospital and the referral of patients from both this unit and that at the Canadian Red Cross Hospital at Taplow.

Constrictive pericarditis is said to occur only in the seropositive form of rheumatoid arthritis, as was the case in the present series (Table). Although rheumatoid nodules have been found in the pericardium at post-mortem examination of patients with rheumatoid arthritis (Bauer and Clark, 1948), we have found no cases reported in which specific rheumatoid changes have been found in a pericardium excised for constrictive $\overrightarrow{\mathrm{F}^{\mathrm{f}}}$ pericarditis.

Gimlette (1959) was of the opinion that patients with constrictive pericarditis associated with? rheumatoid disease had severe myocardial involve $\mathbb{D}$ ment and that pericardiectomy did not improves the condition greatly, the patients continuing tobe troubled by the myocardial disease. Later authors have not agreed with this opinion, and in $\vec{\omega}$ the present series four of the five patients have had an excellent result. There therefore seems little evidence for Gimlette's pessimism.

A significant number of patients with rheu $\omega$ matoid arthritis (up to $40 \%$ in some studies) develop some form of pericarditis (Connolly andoo Burchell, 1961; Parker and Cooper, 1961; Wilkin-오 son, 1962) and display non-constrictive adhesionsat post-mortem examination (Bauer and Clark $\subseteq$ 1948; Bywaters, 1950; Sokoloff, 1953). It is, there fore, only a very small percentage of cases in which the pericarditis progresses to fibrosis and constriction.

Steroid therapy has been given to severab patients, both in the present series and in other reported cases, throughout the course of theo rheumatoid disease process, yet these patients haveo still developed chronic constrictive pericarditis. Steroid therapy, therefore, appears to play no part $\overrightarrow{5}$ in preventing progression to pericardial fibrosis 3 and constriction (Connolly and Burchell, 1961, 居 Tubbs et al., 1964).

There are also a very few well-documented cases in which pericarditis has been a presenting feature of rheumatoid disease in patients hitherto com-x pletely well. This has been followed, sometimes a? few weeks after complete clinical resolution of pericarditis, by the typical arthritic features? (Gimlette, 1959; Glyn and Pratt-Johnson, 1963).

The exact diagnosis in the case of the patient who showed a persistent eosinophilia remains un $\rightarrow$ clear. Systemic lupus erythematosus was thoughte. to be most likely. However, there have been re+N ports of pericarditis occurring in hyper-eosinophilic states, such as tropical eosinophilia (Vakil, 1961 Singh et al., 1974). The case outlined appears to bew the first reported in Britain of constrictive perio carditis associated with such a hyper-eosinophilico state.

Although pericarditis is a common feature of systemic lupus erythematosus, and, as in rheumatoid arthritis, may be symptomatically silen and noted only at necropsy (Jarcho, 1936? Brigden et al., 1960, Shearn, 1959), constrictive@ pericarditis is an extremely rare complication of this disease. Fibrinous adhesions have been found in the pericardial space at necropsy, but it haf 
been thought that constriction did not occur (McKusick and Harvey, 1955; Gimlette, 1959; Shearn, 1959) until Yurchak and his colleagues reported one such case in 1965, which appears to remain unique.

We thank Dr. B. Bresnihan of the Department of Rheumatology, Hammersmith Hospital, for advice on certain aspects of this paper.

\section{References}

American Rheumatism Association (1959). Primer on the rheumatic diseases. Part 1. Journal of the American Medical Association, 1717, 1205-1220.

Bauer, W., and Clark, W. S. (1948). The systemic manifestations of rheumatoid arthritis. Transactions of the Association of American Physicians, 61, 339342.

Brigden, W., Bywaters, E. G. L., Lessof, M. H., and Ross, I. P. (1960). The heart in systemic lupus erythematosus. British Heart Journal, 22, 1-16.

Bywaters, E. G. L. (1950). The relation between heart and joint disease including 'rheumatoid heart disease' and chronic post-rheumatic arthritis (type Jaccoud). British Heart Journal, 12, 101-103.

Connolly, D. C., and Burchell, H. B. (1961). Pericarditis: a ten-year survey. American Journal of Cardiology, 7, 7-14.

Dayem, M. K. A., Wasfi, F. M., Bentall, H. H., Goodwin, J. F., and Cleland, W. P. (1967). Investigation and treatment of constrictive pericarditis. Thorax, 22, 242-252.

Gimlette, T. M. D. (1959). Constrictive pericarditis. British Heart Journal, 21, 9-16.

Glyn, J. H., and Pratt-Johnson, J. H. (1963). Rheumatoid pericarditis. British Medical Journal, 1, 262.

Jarcho, S. (1936). Lupus erythematosus associated with visceral vascular lesions. Bulletin of the Johns Hopkins Hospital, 59, 262-289.
Kennedy, W. P. U., Partridge, R. E. H., and Matthew, M. B. (1966). Rheumatoid pericarditis with cardiac failure treated by pericardiectomy. British Heart Journal, 28, 602-608.

McKusick, V. A., and Harvey, A. M. (1955). Diseases of the pericardium. In Advances in Internal Medicine, Volume VII, edited by W. Dock and I. Sapper, pp. 157-200. The Year Book Publishers, Chicago.

McMurray, C., Cayer, D., and Cornatzer, W. E. (1951). Chronic adhesive pericarditis due to the rheumatic state, associated with liver damage, serous effusions, and pigmentation. Gastroenterology, 17, 294-303.

Parker, R. C., and Cooper, H. R. (1961). Acute idiopathic pericarditis. Journal of the American Medical Association, 147, 835-839.

Shearn, M. A. (1959). The heart in systemic lupus erythematosus. American Heart Journal, 58, 452466.

Singh, M. M., Sharma, S. K., and Patney, N. L. (1974). Tropical eosinophilic pericarditis. Indian Heart Journal, 26, 261-263.

Sokoloff, L. (1953). The heart in rheumatoid arthritis. American Heart Journal, 45, 635-643.

Tubbs, O. S., Slade, P. R. H., and Turner-Warwick, M. (1964). Constrictive pericarditis in association with rheumatoid arthritis. Thorax, 19, 555-560.

Vakil, R. J. (1961). Cardiovascular involvement in tropical eosinophilia. British Heart Journal, 23, 578586.

Wilkinson, M. (1962). Rheumatoid pericarditis. British Medical Journal, 2, 1723-1726.

Yurchak, P. M., Levine, S. A., and Gorlin, R. (1965). Constrictive pericarditis complicating disseminated lupus erythematosus. Circulation, 31, 113-118.

Requests for reprints to: D. K. C. Cooper, FRCS, Thoracic Unit, Hospital for Sick Children, Great Ormond Street, London WC1. 